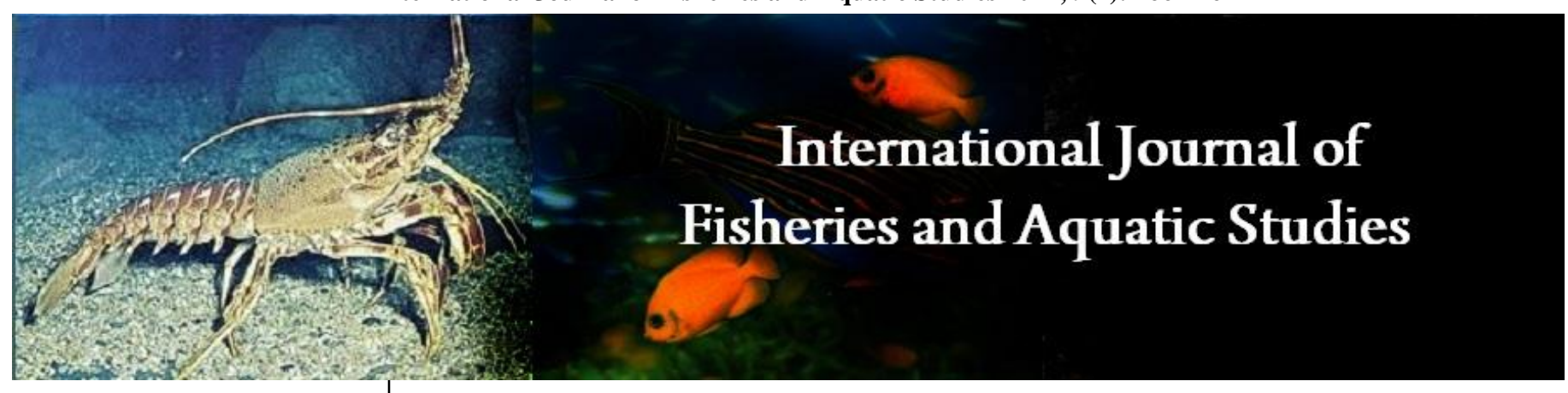

E-ISSN: 2347-5129

P-ISSN: 2394-0506

(ICV-Poland) Impact Value: 5.62

(GIF) Impact Factor: 0.549

IJFAS 2021; 9(2): 266-276

(C) 2021 IJFAS

www.fisheriesjournal.com

Received: 19-01-2021

Accepted: 22-02-2021

Yetunde Agbeja

Department of Aquaculture and

Fisheries Management,

University of Ibadan, Nigeria

Elizabeth Oluyede

Department of Aquaculture and

Fisheries Management,

University of Ibadan, Nigeria

Victor Oyedepo

Department of Aquaculture and

Fisheries Management,

University of Ibadan, Nigeria
Corresponding Author: Yetunde Agbeja

Department of Aquaculture and

Fisheries Management,

University of Ibadan, Nigeria

\section{Socio-economic characteristics assessment and livelihood coping strategies of small-scale fisheries in Ogun waterside local government area, Nigeria}

\author{
Yetunde Agbeja, Elizabeth Oluyede and Victor Oyedepo
}

DOI: https://doi.org/10.22271/fish.2021.v9.i2d.2463

\begin{abstract}
Fish plays a crucial role in food security and serve as a rich source of nutrient. It also provides jobs and income especially through small-scale fisheries and aquaculture practice in developing countries. However, fisheries are faced with numerous problems particularly that of declining stocks, which threatens the rural populace livelihood. This paper reports the socio-economic characteristics and livelihood coping strategies of fishers in a rural community of Ogun waterside Local Government Area of Ogun State, Nigeria. This is with the view to providing information to policy makers towards improving the livelihoods of the rural community, whilst aiming for sustainable fisheries management.

The study adopted a quantitative research design of survey type based on a population of fishers including marketers, processors and members of their household in the study area. A two-stage random sampling technique was used for the survey to select the respondents. The first stage involved random selection of villages from LGA, which are Iwopin, Agbalegiyo, Makun-Omi and Ebute Oni. In the second stage the fishers including marketers, processors and members of their household were randomly selected from the four villages.

A semi-structured questionnaire was used to elicit response from 197 fishers randomly selected for the study. Data collected from the study were analysed using descriptive statistics, multiple response analysis, and profitability analysis. The result of the study revealed the socio-economic characteristics of the fishers and their access to social assets. A comparative analysis of the coping or adaptive strategies to sustaining livelihood in the area indicated that the fishers employed reduction of food intake, sought support from relatives or migrate to another site.
\end{abstract}

Keywords: Small-Scale Fisheries, Ogun Waterside, Rural Community, Fishers

\section{Introduction}

Fishing is an ancient human practice that comprised the act of catching fish (aquatic product) either by hand gathering, spearing, netting, angling and trapping for food. The aquatic products include fresh water and ocean fish, shell fish, plankton, as well as aquatic mammals. Fisheries play very important roles for food security and livelihoods and income generation most especially in developing countries of the world. The demand for fish in the world has been on the increase due to increasing human population and the health benefits attributable to the consumption of fish amongst others (Global Aquaculture Alliance, 2019; Amundson, et al. 2019) ${ }^{[1,2]}$.

Fisheries and aquaculture remain important sources of food, nutrition, income and livelihoods for hundreds of millions of people globally making fish one of the most traded food commodities in the world, with more than half of fish exports by value originating in developing countries (FAO 2015) ${ }^{[3]}$. Worldwide, over 38 million people are employed in fisheries and aquaculture practices and about 95percent of those engaged in it are from developing countries and most often, involved in small-scale fisheries. Apart from fish being an important source of food security for fishers' household, incomes derived from fisheries sector or from fish trade is often more important as a form of contribution to food security (Adeleke and Fagbenro, 2013) ${ }^{[4]}$.

In Nigeria, fisheries-related activities provide important sources of livelihood with more than 6 million coastal and riverine artisanal fishers fishing the $46,300 \mathrm{~km}^{2}$ of maritime area and 125 , 
$470.82 \mathrm{~km}^{2}$ of inland water bodies. They contribute $85 \%$ of domestic fish consumption in Nigerian (Fish for all summit, 2005) ${ }^{[6]}$. Nigeria is a coastal country with $800 \mathrm{Km}$ of coastline and maritime area of 46,000 $\mathrm{Km}^{2}$ (0-20 m depth), an Exclusive Economic Zone (EEZ) area of 210,900 $\mathrm{Km}^{2}$ and a narrow Continental Shelf of between 4.81 and $27.78 \mathrm{Km}$ in the Gulf of Guinea (Udolisa et al., 1994) ${ }^{[5]}$. Nigeria is also blessed with inland water, brackish water, fisheries resources and the fishery is exclusively artisanal with an annual potential yield of 55,000 metric tons of freshwater fishes (Ita, 1993). Apart from being an income earner to many Nigerians especially people in coastal, water ways and lake.

areas of the country, it has a value chain in areas such as fish processing, marketing, recreation, tourism, sport, medicine, fisheries research, etc. (Adedokun et al., 2006) ${ }^{[8]}$.

The Nigeria fisheries sub-sector contributes about $3 \%-4 \%$ to the country's annual GDP and is an important contributor to the population's nutritional requirements, constituting about 50 percent of animal protein intake (Lawal et al., 2016) ${ }^{[9]}$. It has been observed by Food and Agriculture Organisation (FAO), a United Nations Agency in 2015 that small-scale fisheries and aquaculture amongst other fisheries subsectors, require the most urgent attention, especially in relation to food security and nutrition policies and processes. The observation was based on the fact that small-scale fisheries contribute around half of global fish catches in developing countries and employ about 90 percent of the world's capture fishers. Also, about 90 to 95 per cent of the small-scale landings are destined for local human consumption. Hence, small-scale fisheries play an important role in directly increasing the availability of nutritious food for local, national and international markets as well as providing a valuable source of income to those directly and indirectly employed in the sector (FAO, 2015) ${ }^{[3]}$. It was however noted that despite the importance and potential of small-scale fisheries, many smallscale fishing communities continue to be marginalized and their contribution to food security and nutrition remains unrealized (FAO, 2015) ${ }^{[3]}$.

According to Chambers and Conway (1992) [10], a "livelihood comprises the capabilities, assets (stores, resources, claims and access) and activities required for a means of living. A livelihood is sustainable when it can cope with and recover from stress and shocks, maintain or enhance its capabilities and assets, and provide sustainable livelihood opportunities for the next generation. Specifically, a livelihood is said to be sustainable when it contributes net benefits to other livelihoods at the local and global levels and both at the longand short-term period. Changes in the fishing sector have increased tremendously over the last quarter of the $20^{\text {th }}$ century and this changes occur at a faster pace than fishers' ability to keep up with them and this has significantly affected their livelihoods in a wide range of ways including declining availability and access to fish resources, climatic shocks and stresses such as floods, droughts, sea-level rise, land erosion, temperature and rainfall fluctuations as well as growing competition amongst the fishers for fishing grounds (Venkatesh, 2006; IPCC, 2007) ${ }^{[11,12]}$. Also, overcapitalization of fishing and post-harvest activities in the market place and other macroeconomic factors that undermine the traditional structures and mechanisms that protect fishers' livelihoods have all put their survival in disarray. (Venkatesh, 2006) ${ }^{[11]}$

There is a need to understand many of these changes as manifestations of particular policy frameworks within which the development and management programmes have worked.
These include the process of policy-making, the way in which policies were translated into programmes, their implementation and their monitoring and evaluation. As a result, the inadequate policies, the livelihoods of coastal fishers are becoming progressively inefficient, unsustainable and weak. Fishers find their security of existence under threat and their ability to meet the basic needs of life eroding. In other words, their poverty is increasing (Venkatesh, 2006) ${ }^{[11]}$. The problem is exacerbated by the growing vulnerability of fishers to natural disasters, which are increasing both in frequency and intensity. Calamities such as coastal and riverbanks flooding for example are serious problems, not only because of the toll they take in human lives, but (often more seriously) because of the damage they cause to the productive assets of a community and to their long-term livelihood security (Venkatesh, 2006) ${ }^{[11]}$.

Livelihood coping strategies are the combination of activities and choices that households opt for in order to survive. They do not only include activities that generate income, but many other kinds of choices, including cultural and social choices, which assemble to make up the primary occupation of a household (Ellis, 1998) [13]. These strategic options may include short term considerations such as ways of earning a living, coping with shocks and managing risk, as well as longer-term aspirations for the future of the family. "People adopt coping strategies in response to livelihood crises. Slowly, the system recovers and households employ a new adapting strategy composed of elements from the former adapting strategy and the coping strategy to develop a new portfolio of livelihood activities" (Korf, 2003) ${ }^{[14]}$.

Despite the contribution of Fisheries and aquaculture to the GDP of Nigeria, many fishers are relatively poor. These may be due to the major constraints to employment opportunities for the people living in the communities. Other constraints include education, health, poor rural infrastructure, electricity, particularly accessibility, water and sanitation facilities. Fishers' livelihoods also depends on various factors including: access to and availability of fish resources, favourable climatic conditions, availability of market etc. and these have been impacted on by opposing environmental factors including climatic shocks and stresses (e.g. floods, droughts, sea-level rise, land erosion, temperature and rainfall fluctuations etc.), competition for fishing grounds and in the marketplace, declining availability of fish resources, overcapitalization of fishing and post-harvest activities (Venkatesh, 2006; IPCC, 2007) ${ }^{[11,12]}$. It therefore becomes necessary to assess livelihood sustainability and coping strategies of small-scale fisheries in Nigeria using Ogun Waterside Local Government area of Ogun State, Nigeria as a case study.

The study is guided by the following research questions:

1. What are the socio-economic characteristics of fishers in the study area?

2. What are the livelihood activities which the respondents in the study area are engaged in?

3. What are the costs, returns and profitability ratio of fish enterprise in the study area?

4. What are the assets the respondents in the study area have access to?

5. What are the coping strategies adopted by the respondents to ensuring food security? 


\section{Methodology \\ Study Area}

The area of study is Ogun Waterside Local Government Area (LGA) in the Ijebu Division of Ogun State. It is located in the eastern part of Ogun state sharing boundaries with Ondo state in the north, Lagos state in the south and Ijebu east LGA in the west About half to three quarter of the length of the LGA is surrounded by water extending from Lagos state to Ondo state; this peculiar feature gave way to the name waterside. The area comprises over 50 towns and villages with headquarter at Abigi: $6^{\circ} 29^{\prime} \mathrm{N} 4^{\circ} 24^{\prime} \mathrm{E} / 6.483^{\circ} \mathrm{N} 4.4^{\circ} \mathrm{E}$ (Olaoye et al..2012) ${ }^{[10]}$, while the main town in this area are Iwopin, Ilushin, Omi, Ibiade, Abigi, Makun-omi, Efire, Ode-omi and Lomiro, the area consists largely of Yoruba speaking people of which, the Ijebus comprise about 70 percent, with the Ikales, Ilajes, Itsekiris and Urhobos making up the remaining 30 percent; all these other culture observe the same customs, uphold values, beliefs and respect similar traditions as the Yorubas It spans over an area of $1,000 \mathrm{~km}^{2}$ and inhabited by an estimated population of 103,200 based on 2016 population census figure resulting in a population density of $103.2 / \mathrm{km}^{2}$. This area also comprises a large expanse of fertile land (soil) rich in organic matter, well drained and deep, which makes it support various crop cultivation especially plantation crops such as oil palm. The major economic activities include: farming, fishing and lumbering. The major agricultural products are cassava, fish, rice, plantain, rubber, and maize. Major natural resources are Timber, wild Oil Palm Trees, and Vast manila forest (Olaoye et al., 2012) ${ }^{[10]}$. The various tourist centres that abound in the LGA includes: Local Government Guest House; Makun-Omi, Iwopin Boat Estate Regatta Beach, IIusin Rubber Estate Guest House and wodikora Okun Beach. The choice of the study area is based on its close proximity to the Atlantic Ocean and its relative endowment with a complex network of streams, rivers, brackish water and in particular the extension of the Lagos (Lekki) Lagoon to the area. It is the only area of the state with a coastline on the bight of Benin and also borders Lagos lagoon.

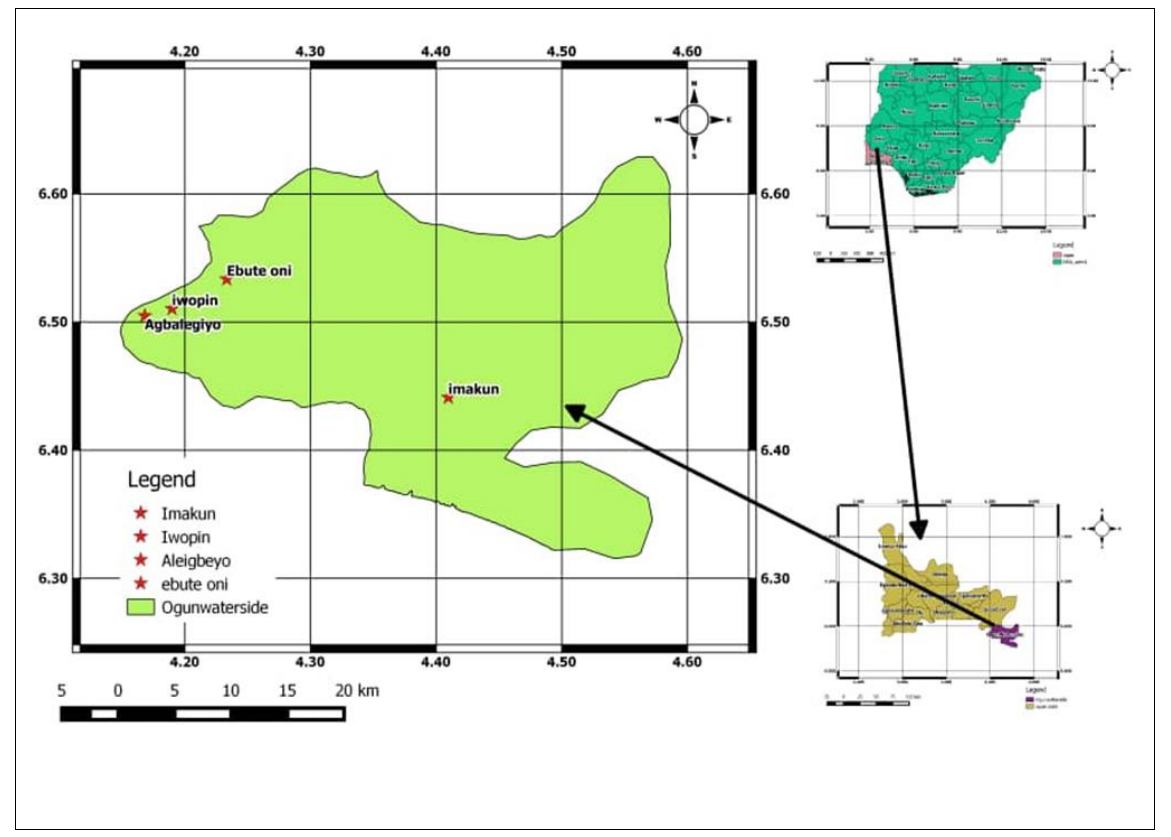

Fig 1: Map of study area

\section{Data source}

A two-stage random sampling technique was used for the survey to select the respondents. The first stage involved random selection of villages from LGA, which are Iwopin, Agbalegiyo, Makun-Omi and Ebute Oni. In the second stage the fishers including marketers, processors and members of their household were randomly selected from the four villages. The population of the study respondents are as indicated in table 1 . The study adopted a quantitative research design of survey type and semi-structured questionnaire was used to elicit response from 197 fishers that were randomly selected.

\section{Data Analysis}

Data collected from the study were analysed using descriptive statistics, multiple response analysis, and profitability analysis.

Multiple Response Analysis: This is a frequency analysis method used when there can be more than one response per participant to a survey question. This was used to analyse the total responses in analysing livelihood, coping and adaptive strategies.

The profitability analysis was calculated using the following formula:

$\Pi=$ TR-TC

$\mathrm{GM}=(\mathrm{TR}-\mathrm{GP}) / \mathrm{TR}$

$\mathrm{TC}=\mathrm{FC}+\mathrm{VC}$

$\mathrm{GM}=\mathrm{TR}-\mathrm{AVC}$

$\mathrm{NFI}=\mathrm{TR}-\mathrm{TC}$

$\mathrm{ROI}=\mathrm{GM} / \mathrm{TC}$

$\mathrm{BCR}=\mathrm{TR} / \mathrm{TC}$

$\mathrm{GRR}=\mathrm{TC} / \mathrm{TR}$

Where

- $\Pi=$ Profit

- $\mathrm{TC}=$ Total Cost

- $\mathrm{FC}=$ Fixed Cost

- $\mathrm{VC}=$ Variable Cost

- $\mathrm{GM}=$ Gross Margin

- $\quad \mathrm{TR}=$ Total Revenue 
- $\quad \mathrm{AVC}=$ Average Variable Cost

- $\quad \mathrm{NFI}=$ Net Farm Income

- $\quad \mathrm{ROI}=$ Rate on Investment
- $\quad \mathrm{BCR}=$ Benefit Cost Ratio

- $\quad$ GRR $=$ Gross Revenue Ratio

Table 1: Sample number and study location

\begin{tabular}{|c|c|c|c|c|c|}
\hline Ogun waterside local government area & Villages & Total Number of Respondents & Fishers & Marketers & Processors \\
\hline 1. & Iwopin & 168 & 90 & 41 & 37 \\
\hline 2. & Agbalegiyo & 10 & 3 & 3 & 4 \\
\hline 3. & Makun-Omi & 16 & 5 & 5 & 6 \\
\hline 4. & Ebute oni & 6 & 2 & 1 & 3 \\
\hline
\end{tabular}

Source: Field survey, 2018

\section{Results and Discussion}

Socioeconomic Background of the Respondents

Table 2a: Percentage Distribution of the socio-economic characteristics of respondents

\begin{tabular}{|c|c|c|c|c|}
\hline Variable & Categories & Frequency $(\%)$ & Mean / Mode & SD \\
\hline \multirow{6}{*}{ Age (years) } & $\leq 20$ years & $8(4.1 \%)$ & & \\
\hline & 21-30 years & $26(13.2 \%)$ & & \\
\hline & $31-40$ years & $87(44.2 \%)$ & & \\
\hline & $41-50$ years & $55(27.9 \%)$ & & \\
\hline & $51-60$ years & $21(10.7 \%)$ & & \\
\hline & Total & $197(100.0 \%)$ & 38.63 & 8.87 \\
\hline \multirow{3}{*}{ Gender } & Male & $102(51.8 \%)$ & & \\
\hline & Female & $95(48.2 \%)$ & & \\
\hline & Total & $197(100.0 \%)$ & Male & 0.501 \\
\hline \multirow{5}{*}{ Marital Status } & Single & $20(10.2 \%)$ & & \\
\hline & Married & $171(86.8 \%)$ & & \\
\hline & Divorced & $2(1.0 \%)$ & & \\
\hline & Widowed & $4(2.0 \%)$ & & \\
\hline & Total & $197(100.0 \%)$ & Married & 0.437 \\
\hline \multirow{7}{*}{ Tribe } & Egun & $2(1.0 \%)$ & & \\
\hline & Yoruba & $189(95.9 \%)$ & & \\
\hline & Igbo & $3(1.5 \%)$ & & \\
\hline & Hausa & $1(0.5 \%)$ & & \\
\hline & Ilorin & $1(0.5 \%)$ & & \\
\hline & Kogi & $1(0.5 \%)$ & & \\
\hline & Total & $197(100.0 \%)$ & Yoruba & 0.460 \\
\hline \multirow[t]{5}{*}{ Religion } & Christianity & $70(35.5 \%)$ & & \\
\hline & Islam & $124(62.9 \%)$ & & \\
\hline & Traditionalist & $3(1.5 \%)$ & & \\
\hline & Others & $0(0 \%)$ & & \\
\hline & Total & $197(100.0 \%)$ & Islam & 0.506 \\
\hline \multirow{5}{*}{ Educational Status } & No formal education & $16(8.1 \%)$ & & \\
\hline & Primary education & $120(60.9 \%)$ & & \\
\hline & Secondary education & $52(26.4 \%)$ & & \\
\hline & Tertiary education & $9(4.6 \%)$ & & \\
\hline & Total & $197(100.0 \%)$ & Primary & 0.675 \\
\hline
\end{tabular}


Table 2b: Demographic Characteristics of Respondents cont.

\begin{tabular}{|c|c|c|c|c|c|c|}
\hline \multirow[t]{2}{*}{ Variables } & & \multicolumn{5}{|c|}{ Marital Status } \\
\hline & & Single & Married & Divorced & Widowed & Total \\
\hline \multirow{6}{*}{ Number of wives } & No wife & 19 & 0 & 2 & 3 & 24 \\
\hline & One wife & 1 & 60 & 0 & 1 & 62 \\
\hline & Two wives & 0 & 88 & 0 & 0 & 88 \\
\hline & Three wives & 0 & 22 & 0 & 0 & 22 \\
\hline & Four wives & 0 & 1 & 0 & 0 & 1 \\
\hline & Total & 20 & 171 & 2 & 4 & 197 \\
\hline \multirow{5}{*}{ Number of Children } & No child & 17 & 0 & 0 & 0 & 17 \\
\hline & $1-3$ children & 3 & 81 & 2 & 4 & 90 \\
\hline & $4-7$ children & 0 & 73 & 0 & 0 & 73 \\
\hline & $\geq 8$ children & 0 & 17 & 0 & 0 & 17 \\
\hline & Total & 20 & 171 & 2 & 4 & 197 \\
\hline \multirow{7}{*}{ Household Size } & \multicolumn{3}{|c|}{ Categories } & \multicolumn{3}{|c|}{ Frequency (\%) } \\
\hline & \multicolumn{3}{|c|}{$0-3$} & \multicolumn{3}{|c|}{$13(6.6 \%)$} \\
\hline & \multicolumn{3}{|c|}{$4-6$} & \multicolumn{3}{|c|}{$78(39.6 \%)$} \\
\hline & \multicolumn{3}{|c|}{$7-9$} & \multicolumn{3}{|c|}{$71(36 \%)$} \\
\hline & \multicolumn{3}{|c|}{$10-12$} & \multicolumn{3}{|c|}{$25(12.7 \%)$} \\
\hline & \multicolumn{3}{|c|}{$\geq 13$} & \multicolumn{3}{|c|}{$10(5.1 \%)$} \\
\hline & \multicolumn{3}{|c|}{ Total } & \multicolumn{3}{|c|}{$197(100.0 \%)$} \\
\hline \multirow{6}{*}{ Years of Fishing Experience } & \multicolumn{3}{|c|}{$1-5$ years } & \multicolumn{3}{|c|}{$35(17.8 \%)$} \\
\hline & \multicolumn{3}{|c|}{$6-10$ years } & \multicolumn{3}{|c|}{$38(19.3 \%)$} \\
\hline & \multicolumn{3}{|c|}{$11-15$ years } & \multicolumn{3}{|c|}{$34(17.3 \%)$} \\
\hline & \multicolumn{3}{|c|}{$16-20$ years } & \multicolumn{3}{|c|}{$44(22.3 \%)$} \\
\hline & \multicolumn{3}{|c|}{$\geq 21$ years } & \multicolumn{3}{|c|}{$46(23.4 \%)$} \\
\hline & \multicolumn{3}{|c|}{ Total } & \multicolumn{3}{|c|}{$197(100.0 \%)$} \\
\hline
\end{tabular}

Source: Field Survey, 2018

The study (Table $2 \mathrm{a} \& \mathrm{~b}$ ) revealed that majority of the respondents (44.2\%) fall between the age group of 31-40 years. It could also be inferred that majority (80\%) of the respondents are below the age of 51 years, which is considered an active age range. The study further revealed that $51.8 \%$ of the respondents were male while $48.2 \%$ were female. Thus, there are more male than female respondents. In similar vein, the classification of marital status revealed that $10.2 \%$ of the respondents are single, while $86.8 \%$ are married. Furthermore, among the fishers in Ogun waterside, the Yorubas are the dominant tribe $(95.9 \%)$ while the Igbos represents about $1.5 \%$, the Egun represents $1 \%$, Hausa represents $0.5 \%$, Ilorin represents $0.5 \%$ and Kogi represents $0.5 \%$. This implies that the Yorubas are the most dominant among the respondents surveyed in the study area.

It was also revealed that majority $(62.9 \%)$ of the respondents are Muslim, $35.5 \%$ were Christians while $1.5 \%$ were traditional worshippers. This implies that Islam is the most dominant religion among the sampled respondents in the study area. The categorization of educational status of the fishers shows that $8.1 \%$ of the respondents have no formal education, $60.9 \%$ have primary education, $26.4 \%$ have secondary education and $4.6 \%$ have tertiary education. This implied that majority of the fishers have had one form of education or the other which tend to have effect on their literacy level and this should be encouraged because livelihood sustainability requires a lot of technical and scientific knowledge to be successfully undertaking.

\section{Livelihood Activities of Fishers in the Study Area}

Fish is the most important natural asset the fishers depend on and Table 3 shows some of the fish species caught and landed at the area.

Table 3: Showing some fish species within Ogun water side

\begin{tabular}{|c|c|}
\hline Family & Species \\
\hline Bagdridae & $\begin{array}{c}\text { Chrysichthys nigrodigitatus } \\
\text { Chrysichthys auratus }\end{array}$ \\
\hline chlidae & $\begin{array}{c}\text { Oreochromiis niloticus } \\
\text { Oreochromis aureus }\end{array}$ \\
\hline Mugilidae & Mugil cephalus \\
\hline Elopidae & Elops lacerta \\
\hline Carangidae & Caranx carangus \\
\hline
\end{tabular}

Source : Field Survey, 2018

Entry into the fishery is open. The fishing trips per day range between 1-2 times, the respondents agreed that high catch is usually between the month of April to July while low catch is around the month of October to January, implying that fish catch is seasonal. 
Table 4: Category of livelihood activities engaged in by fishers

\begin{tabular}{|c|c|c|c|c|}
\hline Variables & Categories & \multicolumn{3}{|c|}{ Activities Engaged In } \\
\hline \multirow{13}{*}{ Primary Occupation } & & Fishing & Fish Marketing & Fish Processing \\
\hline & Fishing & $97(97.0 \%)$ & $1(2.0 \%)$ & $0(0.0 \%)$ \\
\hline & Fish farming & $0(0.0 \%)$ & $0(0.0 \%)$ & $0(0.0 \%)$ \\
\hline & Farming (Farm Activities) & $0(0.0 \%)$ & $0(0.0 \%)$ & $0(0.0 \%)$ \\
\hline & Civil Service & $0(0.0 \%)$ & $0(0.0 \%)$ & $0(0.0 \%)$ \\
\hline & Politician & $0(0.0 \%)$ & $0(0.0 \%)$ & $0(0.0 \%)$ \\
\hline & Trading & $1(1.0 \%)$ & $1(2.0 \%)$ & $8(17.0 \%)$ \\
\hline & Fish Processing & $0(0.0 \%)$ & $0(0.0 \%)$ & $39(83.0 \%)$ \\
\hline & Private company work & $0(0.0 \%)$ & $0(0.0 \%)$ & $0(0.0 \%)$ \\
\hline & Artisan & $1(1.0 \%)$ & $1(2.0 \%)$ & $0(0.0 \%)$ \\
\hline & Fish Marketing & $0(0.0 \%)$ & $47(94.0 \%$ & $0(0.0 \%)$ \\
\hline & Others & $1(1.0 \%)$ & $0(0.0 \%)$ & $0(0.0 \%)$ \\
\hline & Total & $100(100.0 \%)$ & $50(100.0 \%)$ & $47(100.0 \%)$ \\
\hline \multirow{7}{*}{ Monthly Income from Primary Occupation } & $<\approx 20,000$ & $18(18.0 \%)$ & $36(72.0 \%)$ & $38(80.9 \%)$ \\
\hline & $\approx 20,001-N 40,000$ & $8(8.0 \%)$ & $14(28.0 \%)$ & $9(19.1 \%)$ \\
\hline & $\$ 40,001-N 60,000$ & $37(37.0 \%)$ & $0(0.0 \%)$ & $0(0.0 \%)$ \\
\hline & $\$ 60,001-\$ 80,000$ & $17(17.0 \%)$ & $0(0.0 \%)$ & $0(0.0 \%)$ \\
\hline & $\$ 80,001-\$ 100,000$ & $1(1.0 \%)$ & $0(0.0 \%)$ & $0(0.0 \%)$ \\
\hline & $>\$ 100,000$ & $19(19.0 \%)$ & $0(0.0 \%)$ & $0(0.0 \%)$ \\
\hline & Total & $100(100.0 \%)$ & $50(100.0 \%)$ & $47(100.0 \%)$ \\
\hline \multirow{12}{*}{ Secondary Occupation } & Fishing & $2(6.1 \%)$ & $2(7.7 \%)$ & $1(4.8 \%)$ \\
\hline & Farming (Farm Activities) & $5(15.2 \%)$ & $1(3.8 \%)$ & $4(19.0 \%)$ \\
\hline & Fish Farming & $4(12.1 \%)$ & $3(11.5 \%)$ & $0(0.0 \%)$ \\
\hline & Civil Service & $4(12.1 \%)$ & $0(0.0 \%)$ & $0(0.0 \%)$ \\
\hline & Artisan & $6(18.2 \%)$ & $2(7.7 \%)$ & $1(4.8 \%)$ \\
\hline & Politician & $0(0.0 \%)$ & $0(0.0 \%)$ & $1(4.8 \%)$ \\
\hline & Fish Marketing & $0(0.0 \%)$ & $2(7.7 \%)$ & $1(4.8 \%)$ \\
\hline & Private Company work & $2(6.1 \%)$ & $0(0.0 \%)$ & $0(0.0 \%)$ \\
\hline & Fish Processing & $0(0.0 \%)$ & $2(7.7 \%)$ & $5(23.8 \%)$ \\
\hline & Trading & $1(3.0 \%)$ & $16(61.5 \%)$ & $8(38.1 \%)$ \\
\hline & Others & $9(27.3 \%)$ & $0(0.0 \%)$ & $0(0.0 \%)$ \\
\hline & Total & $33(100.0 \%)$ & $28(100.0)$ & $21(100.0 \%)$ \\
\hline \multirow{5}{*}{ Monthly Income from Secondary Occupation } & $<220,000$ & $20(48.8 \%)$ & $25(92.6 \%)$ & $20(95.2 \%)$ \\
\hline & $\approx 20,001-N 40,000$ & $8(19.5 \%)$ & $2(7.4 \%)$ & $1(4.8 \%)$ \\
\hline & $\$ 40,001-\$ 60,000$ & $11(26.8 \%)$ & $0(0.0 \%)$ & $0(0.0 \%)$ \\
\hline & $\$ 60,001-\$ 80,000$ & $2(4.9 \%)$ & $0(0.0 \%)$ & $0(0.0 \%)$ \\
\hline & Total & $41(100.0 \%)$ & $27(100.0 \%)$ & $21(100.0 \%)$ \\
\hline
\end{tabular}

Source: Field Survey, 2018

The study (Table 4) analysed the livelihood activities among fishers in the study area. The result shows that about $50.0 \%$ of the respondents choose "fishing" as their main primary occupation, followed by fish marketing and then fish processing. It was discovered that $37.0 \%$ of those who engage in "fishing" as their primary occupation earns between $\$ 40,001$ - $\$ 60,000,19.0 \%$ earn above $\$ 100,000,18.0 \%$ earn less than $\$ 20,000,17.0 \%$ earn between $\$ 60,001-\$ 80,000$, $8.0 \%$ earn between $\$ 20,001$ - $¥ 40,000$ while $1.0 \%$ earn between $\$ 80,000$ - $\$ 100,000$. However, respondents' engaged in "fish marketing" and fish processing" do not earn more than $\$ 40,000$ on monthly basis. Despite the income earning differentials, the result revealed that those with fishing as their main occupation earn greater income compared to other groups.

The result of the analysis on secondary occupation of the fishers in the study area revealed that for fishers who engaged in fishing activities, most are also involved in artisanal, farming (farm activities), fish farming, civil service and fishing representing $18.2 \%, 15.2 \%, 12.1 \%, 12.1 \%$ and $6.1 \%$, respectively. For those engaged in fish marketing, most are involved in trading and fish farming representing $61.5 \%$ and $11.5 \%$, respectively. For those engaged in fish processing, most are involved in trading, fish processing and farming (farm activities as their secondary occupation representing about $38.1 \%, 23.8 \%$ and $19 \%$, respectively.

\section{Access to assets by Fishers in the Study Area}


Table 5: Analysis of Respondents on their access to social assets

\begin{tabular}{|c|c|c|c|c|c|c|}
\hline Assets & \multicolumn{2}{|c|}{ Fishing } & \multicolumn{2}{c|}{ Fish Marketing } & \multicolumn{2}{c|}{ Fish Processing } \\
\hline & Rank & Percent of cases & Rank & Percent of cases & Rank & Percent of cases \\
\hline Access to land & $10^{\text {th }}$ & $49.0 \%$ & $7^{\text {th }}$ & $52.0 \%$ & $9^{\text {th }}$ & $25.5 \%$ \\
\hline Access to sufficient water & $1^{\text {st }}$ & $96.0 \%$ & $1^{\text {st }}$ & $100.0 \%$ & $1^{\text {st }}$ & $100.0 \%$ \\
\hline Own a vehicle & $8^{\text {th }}$ & $53.0 \%$ & $12^{\text {th }}$ & $0.0 \%$ & $12^{\text {th }}$ & $2.1 \%$ \\
\hline Access to a vehicle & $3^{\text {rd }}$ & $89.0 \%$ & $1^{\text {st }}$ & $100.0 \%$ & $1^{\text {st }}$ & $100.0 \%$ \\
\hline Renting of room & $6^{\text {th }}$ & $73.0 \%$ & $6^{\text {th }}$ & $76.0 \%$ & $6^{\text {th }}$ & $74.5 \%$ \\
\hline Owning a living quarter & $11^{\text {th }}$ & $40.0 \%$ & $9^{\text {th }}$ & $22.0 \%$ & $8^{\text {th }}$ & $29.8 \%$ \\
\hline Access to electricity & $5^{\text {th }}$ & $84.0 \%$ & $5^{\text {th }}$ & $92.0 \%$ & $5^{\text {th }}$ & $83.0 \%$ \\
\hline Access to good roads & $1^{\text {st }}$ & $96.0 \%$ & $4^{\text {th }}$ & $96.0 \%$ & $4^{\text {th }}$ & $89.4 \%$ \\
\hline Access to extension services & $8^{\text {th }}$ & $53.0 \%$ & $9^{\text {th }}$ & $22.0 \%$ & $10^{\text {th }}$ & $21.3 \%$ \\
\hline Access to storage facilities & $12^{\text {th }}$ & $6.0 \%$ & $11^{\text {th }}$ & $8.0 \%$ & $7^{\text {th }}$ & $36.2 \%$ \\
\hline Access to health care system & $4^{\text {th }}$ & $85.0 \%$ & $1^{\text {st }}$ & $100.0 \%$ & $1^{\text {st }}$ & $100.0 \%$ \\
\hline Access to credit facilities & $7^{\text {th }}$ & $58.0 \%$ & $8^{\text {th }}$ & $24.0 \%$ & $11^{\text {th }}$ & $19.1 \%$ \\
\hline
\end{tabular}

Table 5 reveals that fishers in the study area generally have access to a large extent to sufficient social assets such as, water, good roads, access to vehicle, rent a room, electricity, health care system as indicated by the percentage of the items which are over $50 \%$. Comparatively, the table reveal that while those engage in fishing have access to extension services, own a vehicle and credit facilities to a large extent, those in fish marketing and fish processing have least access to those assets. Similarly, fishers who are into fish marketing have to a large extent access to land compared to those into fishing and fish processing. However, fishers generally have least access to living quarters and storage facilities based on the percentages which were below $50 \%$.

\section{Food Security Coping Strategies Adopted by Fishers in the Study Area}

Table 6a: Coping and Adaptive Strategies adopted by those engaged in fishing

\begin{tabular}{|c|c|c|}
\hline Coping / Adaptive Strategies & $\mathbf{N}$ & Percent of Cases \\
\hline Reduction of food intake & $1^{\text {st }}$ & $97.0 \%$ \\
\hline Support from relatives & $2^{\text {nd }}$ & $96.0 \%$ \\
\hline Provision of labour & $3^{\text {rd }}$ & $83.0 \%$ \\
\hline Leasing of fishing gears & $4^{\text {th }}$ & $75.0 \%$ \\
\hline Loans from co-operatives societies & $5^{\text {th }}$ & $55.0 \%$ \\
\hline Diversification into other businesses & $6^{\text {th }}$ & $51.0 \%$ \\
\hline Leasing of Land & $7^{\text {th }}$ & $50.0 \%$ \\
\hline Obtaining goods on credit & $8^{\text {th }}$ & $35.0 \%$ \\
\hline Hunting of animals & $9^{\text {th }}$ & $20.0 \%$ \\
\hline Migration & $10^{\text {th }}$ & $11.0 \%$ \\
\hline Rearing of crops and other agricultural practices & $11^{\text {th }}$ & $8.0 \%$ \\
\hline Selling owned properties and / or items & $12^{\text {th }}$ & $6.0 \%$ \\
\hline Buying of second-hand materials (clothes, pots, plates etc) & $12^{\text {th }}$ & $6.0 \%$ \\
\hline Funds from Insurance & $13^{\text {th }}$ & $5.0 \%$ \\
\hline Rearing / sale of livestock & $14^{\text {th }}$ & $3.0 \%$ \\
\hline Relocate to less expensive houses & $15^{\text {th }}$ & $2.0 \%$ \\
\hline Delay payment of loans and goods bought on credit & $16^{\text {th }}$ & $1.0 \%$ \\
\hline
\end{tabular}

Table 6b: Coping and Adaptive Strategies adopted by those engaged in fish marketing

\begin{tabular}{|c|c|c|}
\hline Coping / Adaptive Strategies & $\mathbf{N}$ & Percent of Cases \\
\hline Support from relatives & $1^{\text {st }}$ & $100.0 \%$ \\
\hline Reduction of food intake & $2^{\text {nd }}$ & $98.0 \%$ \\
\hline Reduce the portion / number of foods served to HH members & $3^{\text {rd }}$ & $92.0 \%$ \\
\hline Diversification into other businesses & $4^{\text {th }}$ & $56.0 \%$ \\
\hline Obtaining goods on credit & $5^{\text {th }}$ & $48.0 \%$ \\
\hline Loans from co-operatives societies & $6^{\text {th }}$ & $22.0 \%$ \\
\hline Delay payment of loans and goods bought on credit & $7^{\text {th }}$ & $18.0 \%$ \\
\hline Migration & $8^{\text {th }}$ & $10.0 \%$ \\
\hline Provision of labour & $9^{\text {th }}$ & $8.0 \%$ \\
\hline Rearing of crops and other agricultural practices & $10^{\text {th }}$ & $4.0 \%$ \\
\hline Rearing / sale of livestock & $11^{\text {th }}$ & $2.0 \%$ \\
\hline Relocate to less expensive houses & $11^{\text {th }}$ & $2.0 \%$ \\
\hline Leasing of land & $11^{\text {th }}$ & $2.0 \%$ \\
\hline
\end{tabular}


Table 6c: Coping and Adaptive Strategies adopted by those engaged in fish processing

\begin{tabular}{|c|c|c|}
\hline Coping / Adaptive Strategies & $\mathbf{N}$ & Percent of Cases \\
\hline Reduction of food intake & $1^{\text {st }}$ & $100.0 \%$ \\
\hline Reduce the portion / number of foods served to HH members & $1^{\text {st }}$ & $100.0 \%$ \\
\hline Support from relatives & $3^{\text {rd }}$ & $97.9 \%$ \\
\hline Delay payment of loans and goods bought on credit & $4^{\text {th }}$ & $48.9 \%$ \\
\hline Diversification into other businesses & $5^{\text {th }}$ & $40.4 \%$ \\
\hline Buying of second - hand materials (clothes, pots, plates etc) & $6^{\text {th }}$ & $34.0 \%$ \\
\hline Migration & $7^{\text {th }}$ & $27.7 \%$ \\
\hline Rearing of crops and other agricultural practices & $8^{\text {th }}$ & $25.5 \%$ \\
\hline Obtaining goods on credit & $9^{\text {th }}$ & $21.3 \%$ \\
\hline Provision of labour & $10^{\text {th }}$ & $6.4 \%$ \\
\hline Loans from co-operative societies & $11^{\text {th }}$ & $2.1 \%$ \\
\hline
\end{tabular}

By ranking of identified adaptation strategies, the study (Tables 6a, 6b and 6c) also revealed the different coping/adaptive strategies adopted by the fishermen, fish marketers and fish processors, respectively with their rankings. The major coping/adaptive strategies employed by the fishermen include reduction of food intake (97.0\%), reducing the portion/amount of food served to household members $(96.0 \%)$ and support from relatives $(83.0 \%)$. On the other hand, rearing/sales of livestock $(2.0 \%)$, relocating to less expensive houses $(1.0 \%)$ and delaying payment of loans/goods bought are least adopted strategies to food security for fishermen.

Costs and Benefits Analyses of Fish Enterprise in the Study Area

Table 7a: Economic Analysis of fish enterprise

\begin{tabular}{|c|c|c|}
\hline ITEMS & Amount ( $)$ & \% Total cost \\
\hline \multicolumn{3}{|c|}{ Variable Cost } \\
\hline Repairs & $604,850.00$ & 6.70 \\
\hline Fuel/firewood & $180,000.00$ & 1.99 \\
\hline Processing & $36,100.00$ & 0.40 \\
\hline Storage & $1,000.00$ & 0.01 \\
\hline Marketing & $5,000.00$ & 0.06 \\
\hline Fish gears & $2,253,000.00$ & 24.94 \\
\hline Others & $1,044,870.00$ & 11.57 \\
\hline Average Variable Cost & $4,124,820.00$ & 45.66 \\
\hline \multicolumn{3}{|c|}{ Fixed Cost } \\
\hline Land & $981,000.00$ & 10.86 \\
\hline Vehicle & $3,675,000.00$ & 40.68 \\
\hline Generator & $252,000.00$ & 2.79 \\
\hline Total Fixed Cost & $4,908,000.00$ & 54.34 \\
\hline Total Cost (TC) & $9,032,820.00$ & \\
\hline Total Revenue (TR) & $11,264,000.00$ & \\
\hline Gross Margin (GM) & $7,139,180.00$ & \\
\hline Net Farm Income & $2,231,180.00$ & \\
\hline
\end{tabular}

Table 7b: Profitability Ratios of fish enterprise

\begin{tabular}{|c|c|}
\hline Ratios & Values \\
\hline Return on Investment & 0.79 \\
\hline Benefit Cost Ratio (BCR) & 1.25 \\
\hline Gross Revenue Ratio & 0.80 \\
\hline Fixed Ratio & 0.44 \\
\hline Operating Ratio & 0.37 \\
\hline
\end{tabular}

Table $7 \mathrm{a}$ and $7 \mathrm{~b}$ give details of the profitability of fish enterprise in the study area. The result reveals that the variable cost accounted for $45.66 \%$ of the total cost the fisheries business in the study area. The fixed cost of production consists of cost of land purchase/rent, vehicle and generator, which accounted for $54.34 \%$ of the total cost. Also, the total cost (TC) of $\$ 9,032,820$ in a year was incurred in

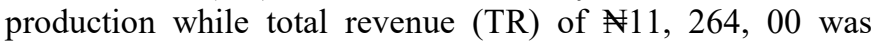
realized with a returning gross margin (GM) of $\$ 7,139,180$ and a net farm income of 2231,180 in a year. This indicates that fish farming in the study area was profitable.

The Benefit Cost Ratio (BCR) was 1.25. This is one of the concepts of discount method of project evaluation, which rule of thumb states that project with ratio greater than one, equal to one or less than one indicate profit, break-even or not profitable, respectively. Since the ratio of 1.25 is greater than one, the enterprise is believed to be profitable. The returns on investment in fish farming in the study area was 0.79 , which implies that for every naira invested, 79 kobo was gained by the respondents. Gross revenue ratio of 0.80 indicated that for every one naira return to fish farm enterprise, 80 kobo was spent. The value of the operating ratio was 0.37 , which implies that about $37 \%$ of the total cost of production was made up of variable cost while the fixed ratio of 0.44 implies that $44 \%$ of the total cost of production was made up of fixed cost. This reveals that the business is worthwhile since the increase in the production with the variable cost would increase the total revenue leaving the fixed cost unchanged.

\section{Discussion of Findings}

Entry into the fishery is open and fish are said to be common property because no individual owns the water body or the fish in it. (Waters, 1991) ${ }^{[16]}$. Hence, fish are harvested on a first-come-first-served basis by anyone with appropriate gear. As fisheries in the study area has been described as seasonal by the respondents, there is need to be mindful of the gear used when there is low catch in order to avoid overfishing.

Age, an important socioeconomic characteristic was identified by this study because its distribution tends to impact productivity, output and adoption of innovation. The study found that the majority of the fishers sampled fell within the age range of 31-40 implying that people in their active years are the most involved in small-scale fisheries in the area. This is not farfetched from the fact that fisheries require energy, adequate attention and a lot of sense of responsibility. These results corroborate the findings of Olowosegun et al., (2004) [17], Olaoye (2010) ${ }^{[18]}$ and Okeowo et al. (2015) ${ }^{[19]}$, who observed that 30 s to 40 s age bracket is a productive age range, which portends better future for fish production and it is considered an economically active age. The result further revealed that artisanal fishing is male dominated. This result can be justified by the assertion of Brummett et al., (2010) ${ }^{[20]}$ that fisheries activities are mostly dominated by men. Though the results showed a little dominance of fisheries by men but the difference is not much. This attest to the fact that the contribution of the women folk in active fishing cannot be undermined. According to Fregene (2002) [21], women are 
mostly fish mongers and are involved in fish processing, petty trading and farming. The result also showed a marital dominated vocation of the sector. It was discovered that majority of the respondents are married (86.8\%). This corroborates the stand that marriage is an indication of economic responsibilities of the respondents in caring for their dependents. Ekong (2003) ${ }^{[22]}$ pointed out that marriage in our society is highly cherished. This assertion was further confirmed by the report of Fakoya (2000) ${ }^{[23]}$ and Oladoja et al., (2008) ${ }^{[24]}$ who opined that marriage confer some level of responsibility and commitment on individuals who are married.

On the fishers' level of education, results showed that over $90 \%$ of the fishers have had one form of formal schooling, which is an indication that they possess basic literacy skills to navigate their daily living. It has long been observed that education plays important role in technology adoption, which invariably improve the fishing and operational efficiency of fishers. Building assets inform of human capital/capabilities through the acquisition of more education, however needs to be encouraged among the fishers because livelihood coping strategies require a lot of technical and scientific knowledge. Forde (1994) ${ }^{[25]}$ stated that the low level of fishing education and social status of the artisanal fishermen were some of the constraints to their fish catching levels and indeed their development. It was established that the fishers have a relatively large household size of 4-6 (36.6\%) and 7-9 $(36.0 \%)$ persons. The finding supports the predominance of large family sizes among the poor in rural areas (KumoluJohnson and Ndimele, 2010) ${ }^{[26]}$ and also an indication that the more educated and urban-based an individual is, the less family-size that individual will keep (Yarhere, 2004) ${ }^{[27]}$. However, small-scale fishing is very labour intensive, requiring labour contribution from the fisher's family, particularly in post-harvest activities. Because of these additional roles undertaken by women and other members of the artisanal fisher's household, many fishers tend to have larger families that can contribute positively to their livelihood.

According to the perception of the fishers on access to social assets shows that access to storage facilities ranked lowest, as fishes are highly perishable, it of necessity to have appropriate and efficient storage system so as to preserve fish and command better price in the market.

The most adopted livelihood coping strategy by fishermen, marketers and processors during periods of low fish catch are reduction of food intake, support from relatives and reduction of food intake or quantity of food served to household members. The result also reveals that diversification into other forms of income generating activities is common among fishers. This finding validates the findings of Hussein and Nelson (1999) ${ }^{[28]}$, who reported that coping strategies are employed seasonally or in response to external shocks (e.g. droughts) by relatively vulnerable households. On the positive side, diversification helps to reduce the risk of livelihood failure by spreading the risk across more than one income source. It also helps to overcome the uneven use of assets (principally labour) caused by seasonality, to reduce vulnerability, to generate financial resources in the absence of credit markets. (Allison and Ellis, 2001) [13] Viewing diversification from the negative side, income diversification can be said to offer the fishers little incentive to alter their dependence on fishing or stop fishing for alternative employment as they already have alternative employment.
Income diversification can cause fishing using unsustainable and destructive methods, particularly open access fishery such as the study area. (Hoorweg, et al., 2006) ${ }^{[30]}$. Further analysis of their coping strategy indicates collection of loans and government support were the least livelihood strategies employed by both the fishers. This reveals the reduced level of collected loans by fishers due to several constraints such as high interest rates, insufficient funds, delay in releasing of funds, collateral security etc. the result also reveals that the support of government towards the respondents is low and should be improved on. Respondents also consider government support, loans from financial institutions and support from relatives as the most efficient and important coping strategies.

\section{Summary and Recommendations}

This study examined the socio-economic characteristics and livelihood coping strategies of fishers of Small-Scale Fisheries in Ogun Waterside Local Government Area of Ogun State, Nigeria, with a view to providing information to policy makers towards improving the livelihoods of the rural community, whilst aiming for sustainable fisheries management. The result of the study shows the socioeconomic and demographic characteristics of the fishers in the study area. Also, some of the assets the fishers have access to from the larger extent to least extent were identified. Equally, Various livelihood coping and adaptation strategies such as reduction of food intake, sourcing of support from relatives and reduction of food intake or quantity of food served to household members as well as diversification into other forms of income generating activities were commonly employed by the fishers in response to certain low income from their smallscale fishing activities. Based on these findings, it was therefore recommended that:

1. Facilitating agricultural ventures and non-farm employment will be a good strategy for supplementing the income of the respondents towards a sustainable livelihood

2. There is a need to organise training programmes directed towards training Fishers in live-skills that can be used in creating jobs in their vicinity as well as provision and improvement of infrastructural facilities such as education, financial markets, potable water and storage facilities

3. Household members should also be trained on the various value-adding skills (value chain apart from processing) in Fisheries

4. There is a need for the government to formulate policies to increase the availability of non- farm jobs in the rural areas.

5. Private sector should be encouraged to create incomegenerating activities in the rural areas to enhance their livelihood diversification activities and ultimately their living standard.

6. There is need for further research on the livelihood coping strategies of household heads in the various coastal and inland water communities in Nigeria.

\section{References}

1. Global Aquaculture Alliance. What is aquaculture, and why do we need it 2019.? Retrieved from https://www.aquaculturealliance.org/blog/what-isaquaculture-why-do-we-need-it/

2. Amundson $\mathrm{CH}$, Brandt AV, Borgstrom GA, Sainsbury 
JC, Pike D, Purrington P F. Commercial fishing. Retrieved 2019.2 from https://www.britannica.com/explore/savingearth/commer cial-fishing

3. FAO. Small-Scale Fisheries 2015. Retrieved from http://www.fao.org/3/a-au832e.pdf

4. Adeleke ML, Fagbenro OA. Livelihood Diversification and Operational Techniques of The Artisanal Fishers in The Coastal Region of Ondo State, Nigeria. International Journal of Innovative Research \& Development. 2013;2(1):262-273.

5. Udolisa REK, Solarin BB, Ambrose EE. A catalogue of small-scale fishing gears in Nigeria. IAFR Publi. 1014/F1 1994;194(102):142.

6. Fish for All Summit. Presentation of Nigeria's Fisheries Resources, Abuja, Nigeria 22-25 August 2005. Retrieved 2005. from https://digitalarchive.worldfishcenter.org/handle/20.500.1 $2348 / 1954$

7. Ita EO. Inland fishery resources of Nigeria. CIFA. Occa. Pap. No. 21. FAO, Rome, 1993, 52.

8. Adedokun OA, Adereti FO, Opele AI. Factors Influencing the Adoption of Fisheries Innovations by Artisanal Fishermen in Coastal Areas of Ogun State, Nigeria. Journal of Applied Science Research, INSnet Publication. 2006;2(11):966- 971.

9. Lawal Jim-Saiki, Obatola PO, Giwa EJ, Alhaji TA. Socio-Economic Analysis of Artisanal Fishing Operation in West and East Axes of Lagos State, Nigeria. World Journal of Agricultural Research 2016;4(1):31-35.

10. Chambers R, Conway GR. Sustainable rural livelihoods: practical concepts for the 21 st century. IDS Discussion paper 1992;296:1-29. ISBN 09037-15589.

11. Venkatesh $\mathrm{S}$. Trends in poverty and livelihoods in coastal fishing communities of Orissa State, India. FAO Fisheries Technical Paper. No. 490. Rome, FAO. 2006, $111 \mathrm{p}$

12. IPCC. Climate change 2007: Impacts, adaptation and vulnerability: Contribution of working group II to the fourth assessment report of the Intergovernmental Panel on Climate Change. In: Parry ML, Canziani OF, Palutikof JP, van der Linden PJ, Hanson CE (eds) Cambridge University Press, Cambridge 2007, 22-78.

13. Ellis F. Household Strategies and Rural Livelihood Diversification. The Journal of Development Studies 1998;35(1):1-38.

14. Korf B. Livelihoods at Risk: Coping Strategies of Waraffected Communities in Sri Lanka. Journal of Agriculture and Rural Development in the Tropics and Subtropics 2003;104(2):129-141. Retrieved from https://www.jarts.info/index.php/jarts/article/view/22/19

15. Olaoye OJ, Idowu AA, Omoyinmi GA, Akintayo IA, Odebiyi OC, Akintayo OA. Socio-Economic Analysis of Artisanal Fisherfolks in Ogun Water-Side Local Government Areas of Ogun State, Nigeria. Globa 1 Journal of Science Frontier Research Agriculture \& Biology 2012;12(4):9-22. Retrieved from https://globaljournals.org/GJSFR_Volume12/2-SocioEconomic-Analysis-of-Artisanal-Fisher-Folks.pdf

16. Waters JR. Restricted Access vs. Open Access Methods of Management: Toward More Effective Regulation of Fishing Effort. Marine Fisheries Review 1991;53(3):10.

17. Olowosegun T, Sanni AO, Sule AM, Bwala RL. Contribution of Women to Fisheries development in
Kainji Lake Basin, In 19th Annual Conference of the Fisheries Society of Nigeria 2004 (FISON) Conference proceeedings 2004, 91-97.

18. Olaoye OJ. Dynamics of the Adoption Process of Improved Fisheries Technologies in Lagos and Ogun States Nigeria. A Ph.D thesis in the Department of Aquaculture and Fisheries Management, University of Agriculture Abeokuta, Ogun State, Nigeria, 2010, 367.

19. Okeowo TA, Bolarinwa JB, Ibrahim D. Socioeconomic Analysis of Artisanal Fishing and Dominant Fish Species in Lagoon Waters of EPE and Badagry Areas of Lagos State. International Journal of Research in Agriculture and Forestry 2015;2(3):38-45.

20. Brummett RE, Youaleu JLN, Tiani AM, Kenmegne. Women's traditional fishery and alternative aquatic resource livelihood strategies in the southern Cameroonian Rainforest. Fisheries Management and Ecology 2010;17:221-230.

21. Fregene BT. Poverty Assessment of Fishing Communities of Lagos State, Nigeria, University of Ibadan, Nigeria (Ph. D. Thesis) 2002, 67.

22. Ekong EE. An Introduction to Rural Sociology. 2nd Edn., Nigeria Dove Educational Publishers, Uyo, Nigeria, 2003, 84.

23. Fakoya EO. Farmers Use of Sustainable Land Management Practices in Ondo State, Nigeria. PhD. Thesis, Department of Agricultural Extension and Rural Development, University of Ibadan 2000, 160.

24. Oladoja MA, Adedoyin SE, Adeokun OA. Training needs of fisherfolks on fishing technologies. Journal of Food Agriculture and Environment Science and Technology 2008;6(1):195-198.

25. Forde AC. Update on Sierra Leone fisheries. IDAF Technical Report No: 69. FAO, Rome, 1994, 9.

26. Kumolu-Johnson CA, Ndimele PE. Length-weight relationships and condition factors of Twenty-one fish species in Ologe lagoon, Lagos, Nigeria, Asian Journal of Agricultural Sciences 2010;2(4):174-179.

27. Yarhere M. A study of Women's Participation in Food Security and Poverty Alleviation in Lagos and Ogun States. In: 19th Annual Conference of the Fisheries Society of Nigeria (FISON) Conf. Proceedings, 2004,. 167-178.

28. Hussein Karim, John Nelson. Sustainable Livelihoods and Diversification. IDS Working Paper 69. London: Institute of Development Studies, 1999.

29. Allison EH, Ellis F. The livelihoods approach and management of small-scale fisheries. Marine Policy 2001;25:377-388.

30. Hoorweg J, Versleijen N, Wangila B, Degen A. Income diversification and fishing practices among artisanal fishers on the malindi-kilifi coast. Paper presented at Coastal Ecology Conference IV, Mombasa. Kenya, 2006. https://openaccess.leidenuniv.nl/bitstream/handle/1887/1 3013/ASC-070744769-129-01.pdf?sequence=1 
